\title{
Perbandingan Kecepatan Fotosintesis Pada Tanaman Sawi Hijau (Brassica juncea) yang diberi Pupuk Organik dan Anorganik
}

\author{
ST. HASBIAH ${ }^{1}$, BAIQ FARHATUL WAHIDAH $^{1}$ \\ ${ }^{1}$ Jurusan Biologi, Fakultas Sains dan Teknologi, UIN Alauddin Makassar \\ J1. Sultan Alauddin 36 Samata, Kab. Gowa 92113 \\ email: baiqfarhatulwahidah@gmail.com
}

\begin{abstract}
This study was conducted to determine the comparison of photosynthetic rate between organic and inorganic plant with mustard greens (Brassica juncea) as sample. The experimental design was a randomized block design with 3 times respectively using compost for organic crops and NPK for inorganic crops. Doses used is $20 \mathrm{~g} / \mathrm{kg}$ soil for both. The results showed an average increase of oxygen pressure in the light reactions of organic crops is $0.123 \mathrm{hPa} / \mathrm{s}$ whereas the inorganic plant is $0.028 \mathrm{hPa} / \mathrm{s}$. The average pressure of oxygen organic crops decreased to $0.104 \mathrm{hPa} / \mathrm{s}$ whereas the inorganic plant $-0.037 \mathrm{hPa} / \mathrm{s}$ in the dark reaction. Analysis of the data in this study using the unpaired $t$ test and the results showed a significant difference between the rate of photosynthesis in plants organic and inorganic.
\end{abstract}

Keywords: dark reaction, inorganic plant, light reaction, organic plant, the rate of photosynthesis

\section{PENDAHULUAN}

Fotosintesis sangat penting bagi semua kehidupan aerobik di bumi karena selain untuk menjaga tingkat normal oksigen di atmosfer, fotosintesis juga merupakan sumber energi bagi hampir semua kehidupan di bumi, baik secara langsung (melalui produksi primer) maupun tidak langsung (sebagai sumber utama energi dalam makanan mereka), kecuali pada organisme kemoautotrof yang hidup di bebatuan atau di lubang angin hidrotermal di laut yang dalam. Tingkat penyerapan energi oleh fotosintesis sangat tinggi, yaitu sekitar 100 terawatt, atau kira-kira enam kali lebih besar daripada konsumsi energi peradaban manusia. Fotosintesis juga menjadi sumber karbon bagi semua senyawa organik dalam tubuh organisme.

Fotosintesis adalah suatu proses biokimia pembentukan zat makanan karbohidrat yang dilakukan oleh tumbuhan, terutama tumbuhan yang mengandung zat hijau daun atau klorofil. Organisme ini berfotosintesis dengan menggunakan zat hara, karbon dioksida, dan air serta bantuan energi cahaya. Fotosintesis dapat berlangsung dalam berbagai cara pada berbagai spesies, beberapa cirinya selalu sama, misalnya prosesnya selalu dimulai dengan energi cahaya diserap oleh protein berklorofil yang disebut pusat reaksi fotosintesis. Pada tumbuhan, protein ini tersimpan di dalam organel yang disebut kloroplas. Sebagian dari energi cahaya yang dikumpulkan oleh klorofil disimpan dalam bentuk adenosin trifosfat (ATP). Sisa energinya digunakan untuk memisahkan elektron dari zat seperti air. Banyak organisme fotosintesis memiliki adaptasi yang mengonsentrasikan atau menyimpan karbondioksida. Pada dasarnya gejala-gejala yang ditampakkan oleh tumbuhan dapat diterangkan berdasarkan prinsip-prinsip kimia dan/atau fisika. Beberapa proses metabolisme telah dapat dijelaskan secara rinci tentang prinsip-prinsip kimia dan fisika yang terlibat, dimana penjelasan ini telah dapat diterima oleh para ahli fisiologi tumbuhan dengan tanpa ada keraguan, misalnya tentang beberapa proses metabolisme dasar, termasuk fotosintesis dan respirasi. Banyak proses yang terjadi dalam tubuh tumbuhan yang penjelasannya secara kimia atau fisika masih bersifat spekulatif. Hal ini merupakan tantangan yang sangat menarik bagi para ahli fisiologi tumbuhan untuk menelusurinya baik melalui pendekatan biokimia maupun pendekatan biofisika Dari suatu organisme, yang mengontrol aktivitas fisiologi dan biokimia di dalam sel sejalan 
dengan arah perkembangannya, tetapi potensi genetik ini hanya akan berkembang apabila ditunjang oleh lingkungan yang cocok, yang memberikan fasilitas kepada organisme dalam melaksanakan aktivitasnya. Karakteristika yang ditampilkan oleh tumbuhan, ditentukan baik oleh genetik maupun lingkungan secara bersama-sama. Sebagai contoh misalnya hilangnya klorofil dari tumbuhan dapat disebabkan oleh faktor genetik maupun lingkungan. Secara genetik tumbuhan mampu mensintesis klorofil, tetapi apabila lingkungannya tidak menunjang, misalnya tidak ada cahaya, maka klorofil tadi tidak akan terbentuk, sebaliknya meskipun lingkungan telah menyediakan segala kebutuhan untuk sintesis klorofil (cahaya, mineral), tetapi kalau secara genetik tumbuhan tersebut tidak mampu membentuk klorofil (misal jamur), maka klorofil tersebut tidak akan terbentuk. Genetik mengontrol pembentukan enzim-enzim yang diperlukan dalam sintesis klorofil.

Sekarang ini banyak tanaman hijau yang dimanfaatkan sebagai suplemen makanan yang baik untuk dikonsumsi tiap hari. Salah satu contohnya adalah sawi hijau. Tanaman ini banyak menjadi alternatif pilihan suplemen makanan yang baik karena selain kandungan gizinya yang cukup juga karena faktor ekonomi yang mudah dijangkau oleh seluruh lapisan masyarakat. Tanaman ini dapat dibudidayakan dilahan yang berpasir dan memiliki suhu yang cukup tinggi serta kelembaban yang sangat rendah (Ridge, 1991).Sayuran serta buah-buahan sangat penting bagi tubuh. Karena kedua makanan tersebut memiliki gizi serta asupan vitamin yang sangat tinggi dan dibutuhkan oleh tubuh kita. Dalam istilah sayuran dan buah-buahan terkenal dua macam jenis yaitu organik dan anorganik. Berbagai jenis sayuran yang kita konsumsi dalam kehidupan sehari-hari. Dalam menanam sayuran diperlukan bibit dan juga lahan yang subur. Namun ada hal lain yang juga harus diperhatikan yaitu pemberian pupuk. Berdasarkan pemberian pupuk inilah sehingga tanaman dibedakan kedalam dua jenis diatas. Sebagai tanaman hijau, sawi memiliki klorofil sebagai tempat berlangsungnya fotosintesis. Klorofil atau pigmen utama tumbuhan juga banyak dimanfaatkan sebagai food suplement yang dimanfaatkan untuk membantu mengoptimalkan fungsi metabolik, sistem imunitas, detoksifikasi, meredakan radang (inflamatorik) dan menyeimbangkan sistem hormonal (Ratnawina, 2011).

Berdasarkan teori yang ada tanaman sawi hijau adalah salah satu tanaman yang memiliki kemampuan untuk berfotosintesis dan pembudidayaannya dapat dilakukan dengan berbagai cara salah satunya dengan cara memberikan pupuk, baik pupuk organik maupun anorganik. Pemberian pupuk dapat meningkatkan unsur hara baik unsur hara makro maupun unsur hara mikro untuk membantu dalam berbagai proses metabolisme yang dilakukan oleh tanaman salah satunya yaitu pada proses fotosintesis sehingga penelitian ini dilakukan untuk mengetahui kecepatan fotosintesis pada tanaman sawi yang telah diberikan pupuk organik dan anorganik kemudian melihat perbandingan kecepatan fotosintesisnya.

\section{METODE}

\section{Preparasi bahan tanam}

a. Membersihkan kotak pemeliharaan.

b. Mengisi kotak pemeliharaan dengan tanah yang telah digemburkan terlebih dahulu.

c. Memberikan pupuk kompos pada kotak 1 dan pupuk NPK pada kotak 2. Pemberian pupuk bertujuan agar masing-masing pupuk bercampur secara merata dengan tanah yang akan ditanami bibit sawi hijau.

\section{Pembibitan tanaman}

a. Menyiapkan wadah persemaian lalu mengisi dengan pasir murni.

b. Menaburkan benih kedalam wadah persemaian.

c. Menyiram dengan menggunakan sprayer atau semprotan.

d. Kemudian diamati selama 5 hari setelah benih ditanam.

e. Setelah berumur 14 hari, benih akan tumbuh menjadi bibit dan siap memindahkan kedalam wadah pemeliharaan untuk melakukan penanaman. 


\section{Penanaman}

a. Membuat lubang sedalam $2 \mathrm{~cm}$ pada wadah pemeliharaan yang sebelumnya telah diberi pupuk.

b. Memindahkan bibit yang telah tumbuh kedalam wadah pemeliharaan dengan jarak tanam $10 \mathrm{~cm}$.

\section{Pemeliharaan}

a. Meletakkan wadah pemeliharaan pada tempat yang terpapar sinar matahari.Jika turun hujan maka wadah dipindahkan ke tempat yang teduh.

b. Menyiram tanaman 1 kali dalam sehari dan sebaiknya dilakukan pada pagi hari.

c. Menggemburkan tanah dan membersihkan wadah pemeliharaan dari gulma yang tumbuh.

d. Memberikan pupuk kompos dengan dosis 2 $\mathrm{gr} / 100 \mathrm{ml}$ air pada kotak pemeliharaan 1 untuk tanaman organik dan pupuk NPK dengan dosis $2 \mathrm{gr} / 100 \mathrm{ml}$ air pada kotak pemeliharaan 2 untuk tanaman anorganik setelah usianya 3 minggu. Pada proses pemeliharaan, dapat dilakukan pengamatan pada jumlah daun (helai) dan warna daun.

Pemanenan. Tanaman yang telah berusia 6 minggu siap dipanen untuk kemudian dijadikan sampel uji pada penelitian ini.

\section{Pengukuran kecepatan fotosintesis}

a. Pengamatan reaksi terang

1. Tanaman yang telah berusia 6 minggu ditimbang beratnya, diukur tingginya dan dihitung jumlah daunnya.

2. Menyiapkan alat pengukuran fotosintesis (Photosynthesis System)

3. Mengisi tabung reaksi dengan air suling dan menambahkan $\mathrm{NaHCO}_{3}$ yang telah dikalibrasi (9 $\mathrm{g}$ dalam $300 \mathrm{~g}$ air suling).

4. Memasukkan tanaman kedalam tabung reaksi yang telah berisi dengan air suling (aquadest) dan $\mathrm{NaHCO}_{3}$.

5. Mengisi gelas kimia dengan akuades, menyalakan lampu sorot sebagai penyinaran selama proses fotosintesis berlangsung. Proses ini dinamakan reaksi terang. Menekan tombol start untuk memulai membaca kurva tekanan sebagai aktivitas produksi $\mathrm{O}_{2}$. Menekan tombol stop jika telah mencapai waktu yang diinginkan pada pengamatan reaksi terang.

6. Mengulangi perlakuan pada tiap-tiap tanaman sawi yang telah diberi pupuk kompos untuk tanaman organik dan pupuk NPK untuk tanaman anorganik masing-masing dilakukan 3 kali pengulangan.

b. Pengamatan reaksi gelap

1. Menambahkan zat pewarna Tartrazin dan Paten Blue-V Natrium pada gelas kimia masing-masing $50 \mathrm{mg}$ hingga terbentuk larutan berwarna hijau

2. Membungkus tabung reaksi yang berisi air dan tanaman uji dengan aluminium foil. Hal ini untuk pengamatan pada reaksi gelap. Kemudian menekan kembali tombol start untuk memulai membaca kurva tekanan pada reaksi gelap

3. Mengulangi perlakuan pada tiap-tiap tanaman sawi yang telah diberi pupuk kompos untuk tanaman organik dan pupuk NPK untuk tanaman anorganik dengan masing-masing dilakukan 3 kali pengulangan.

\section{Analisis Data}

Analisis data pada penelitian ini menggunakan uji $t$ atau $t$ test.

\section{HASIL}

Berdasarkan analisis data yang diperoleh setelah pengamatan yang dilakukan dengan menggunakan alat Photosynthesis System of $\mathrm{O}_{2} \quad$ Pressure pada tanaman yang telah diberikan perlakuan yang berbeda yaitu sawi hijau yang telah diberikan pupuk kompos dan sawi hijau yang telah diberikan pupuk NPK didapatkan hasil rerata yang dijabarkan pada tabel 1 dan tabel 2 sebagai berikut:

Tabel 1. Rata-rata peningkatan tekanan Oksigen $\left(\mathrm{O}_{2}\right)$ pada reaksi terang

Perlakuan

Tekanan Oksigen $(\mathrm{hPa} / \mathrm{s})$ 


\begin{tabular}{ccccc}
\hline Organik & 0.097 & 0.169 & 0.103 & 0.123 \\
\hline Anorganik & 0.025 & 0.034 & 0.024 & 0.028
\end{tabular}

Tabel 2. Rata-rata penurunan tekanan Oksigen $\left(\mathrm{O}_{2}\right)$ pada reaksi gelap

\begin{tabular}{ccccc}
\hline Perlakuan & \multicolumn{4}{c}{ Tekanan Oksigen $(\mathrm{hPa} / \mathrm{s})$} \\
\hline Organik & 1 & 2 & 3 & Rata-rata \\
\hline Anorganik & -0.085 & -0.142 & -0.085 & -0.104 \\
\hline & -0.037 & -0.034 & -0.041 & -0.037 \\
\hline
\end{tabular}

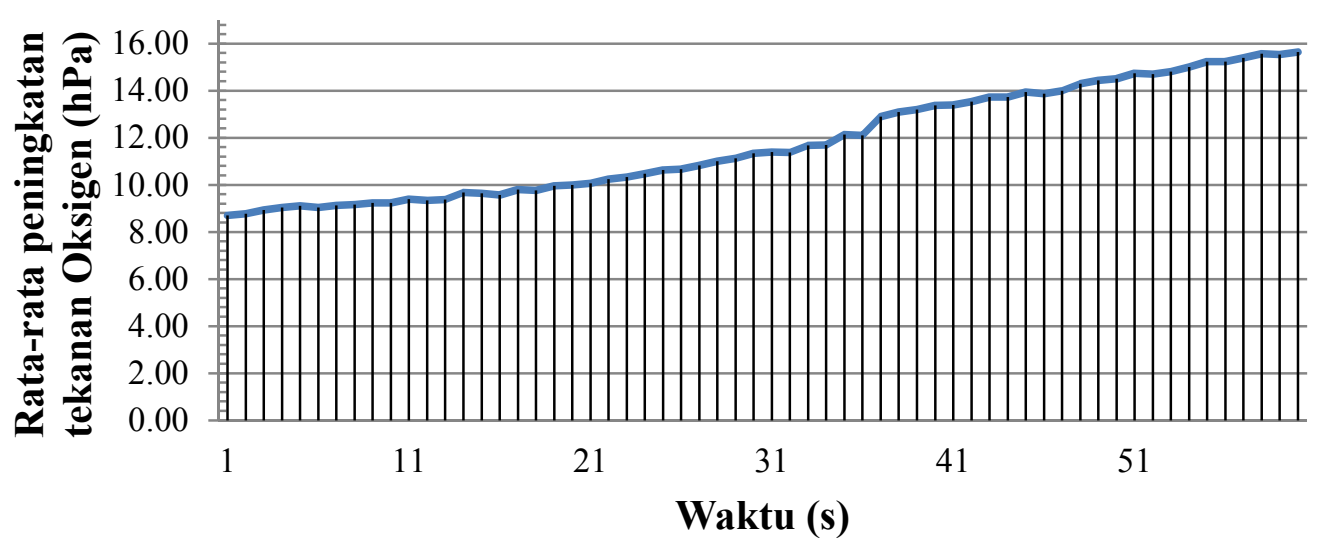

Gambar 1. Grafik rata-rata peningkatan tekanan oksigen $\left(\mathrm{O}_{2}\right)$ yang dihasilkan tanaman organik pada reaksi terang

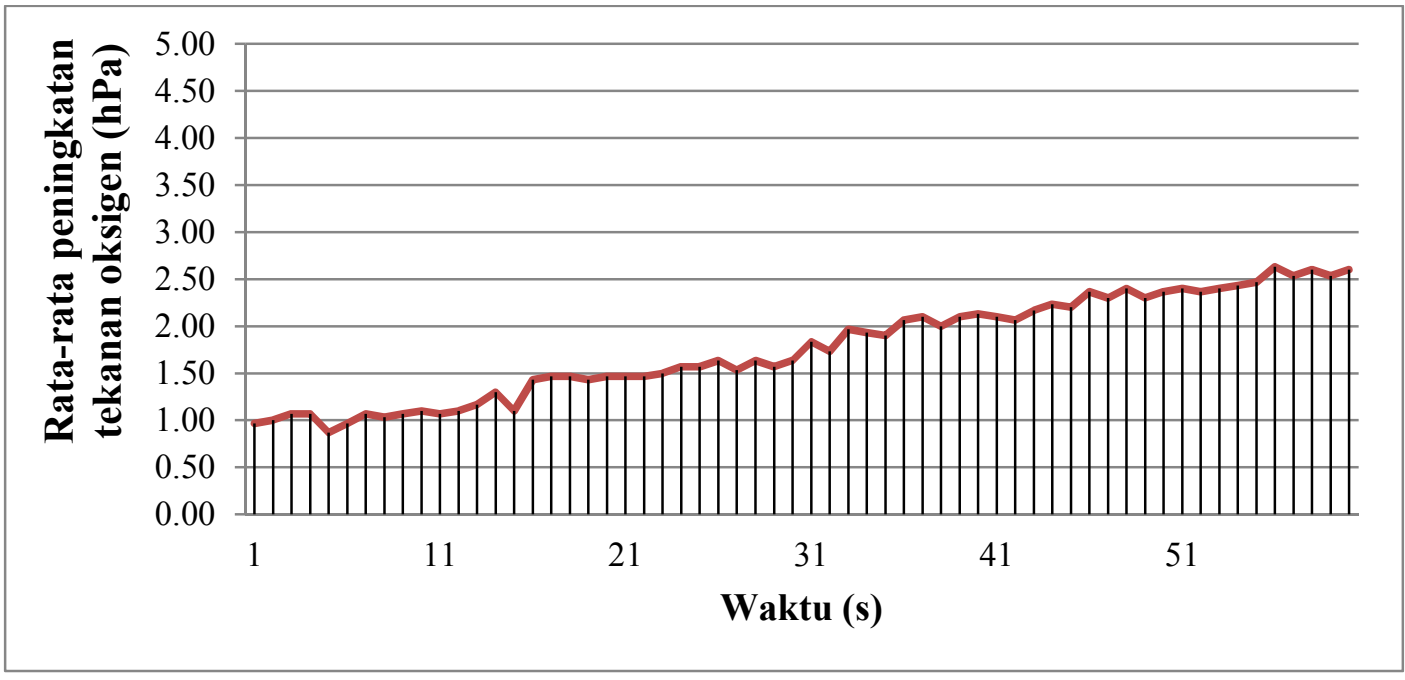

Gambar 2. Grafik rata-rata peningkatan tekanan oksigen $\left(\mathrm{O}_{2}\right)$ yang dihasilkan tanaman anorganik pada reaksi terang 


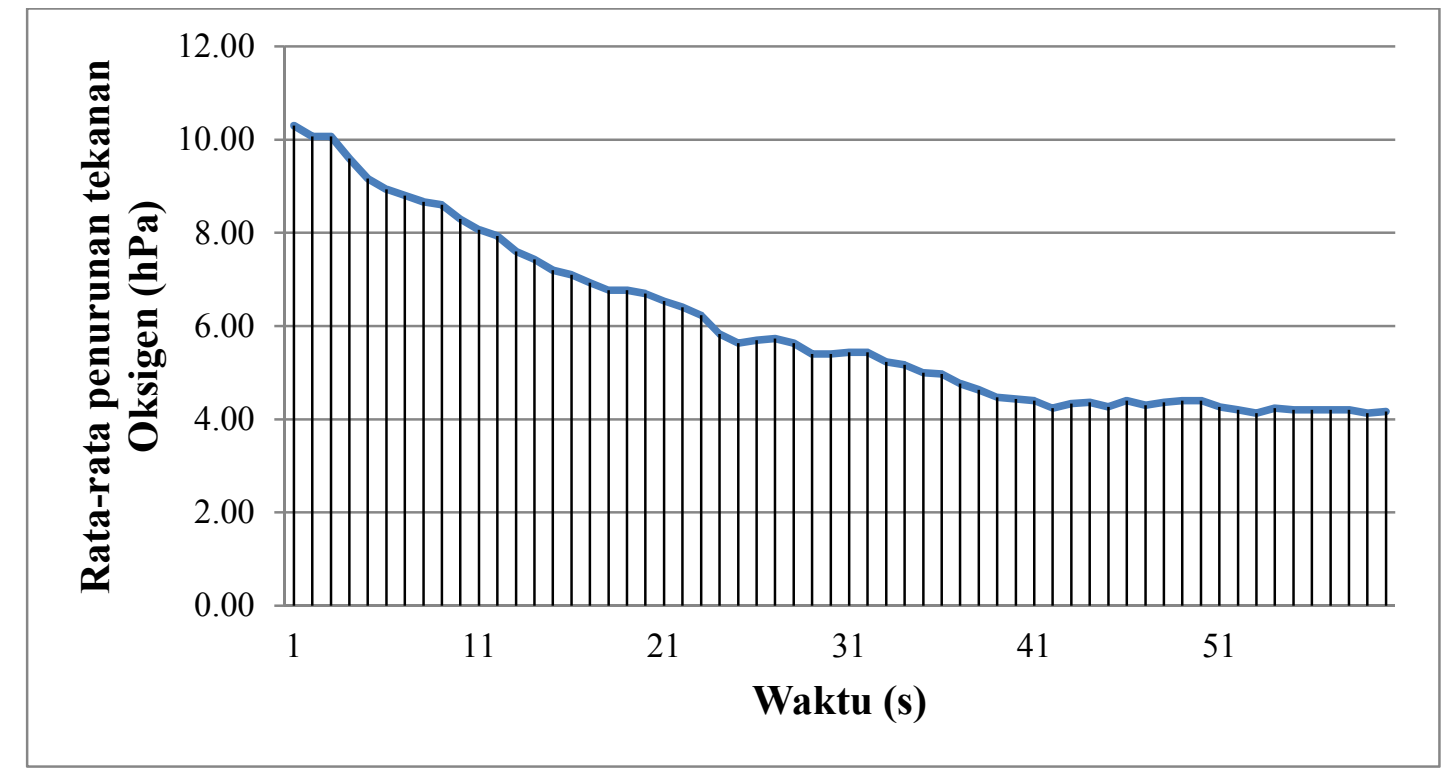

Gambar 3. Grafik rata-rata penurunan tekanan oksigen $\left(\mathrm{O}_{2}\right)$ tanaman organik pada reaksi gelap

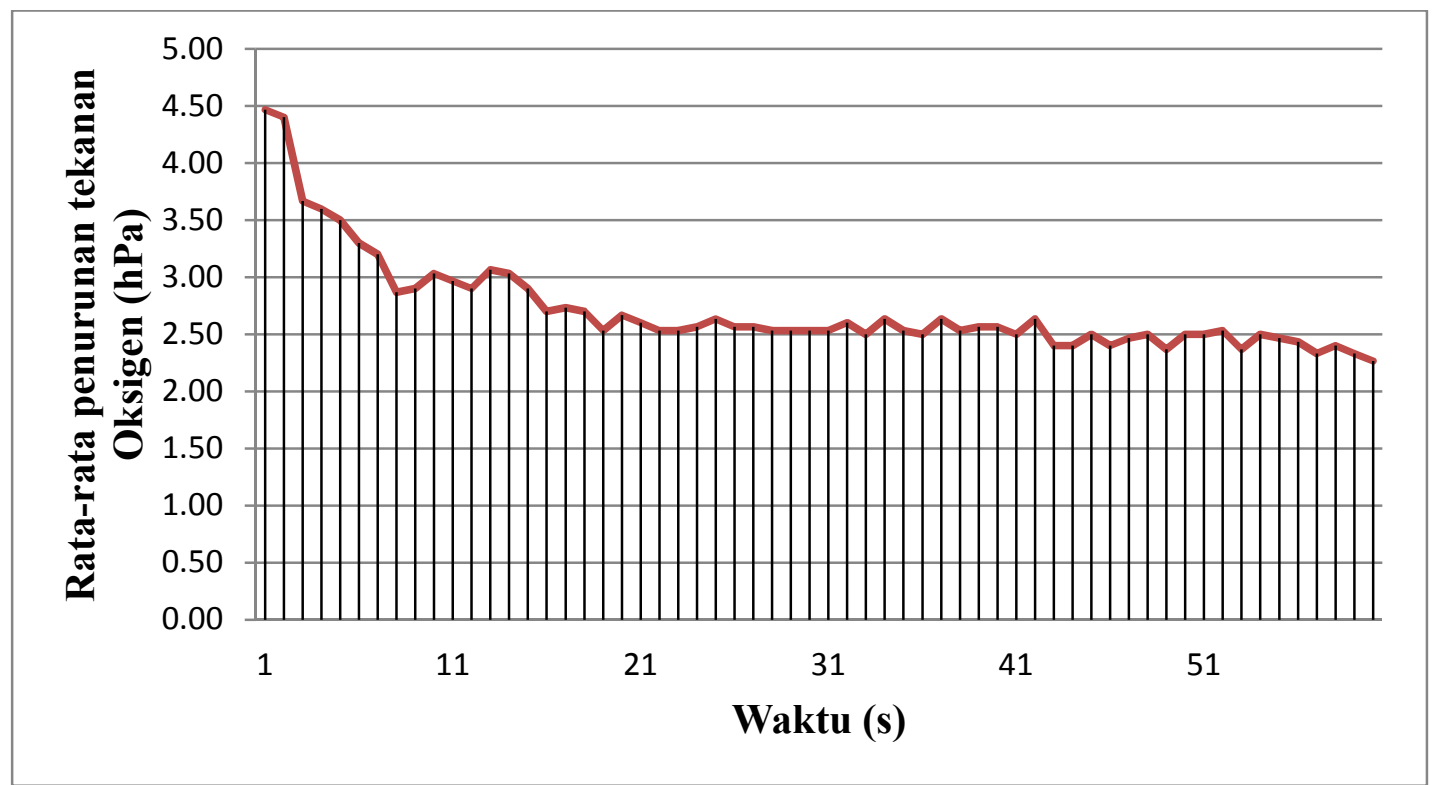

Gambar 4. Grafik rata-rata penurunan tekanan oksigen $\left(\mathrm{O}_{2}\right)$ tanaman anorganik pada reaksi gelap

Tabel 3. Rerata data pertumbuhan tanaman sawi organik dan sawi anorganik Jenis tanaman Jumlah daun (helai)

\begin{tabular}{cccc}
\hline Sawi organik & 7 & Hijau & 4.1092 \\
\hline Sawi anorganik & 6 & Hijau & 3.706
\end{tabular}


Peningkatan dan penurunan tekanan oksigen tiap detik antara tanaman organik dan anorganik dapat diamati pada grafik gambar 1, 2, 3 dan 4. Dari hasil pengamatan grafik tersebut diperoleh beberapa perbedaan yang signifikan antara tanaman organik dengan tanaman anorganik, baik dalam proses reaksi terang maupun pada proses reaksi gelap.

Berdasarkan pengamatan terhadap pertumbuhan yang dilakukan selama 6 minggu didapatkan rerata antara tanaman sawi organik dan tanaman sawi anorganik terlihat pada tabel 3. Dari data menunjukkan bahwa antara tanaman sawi organik dan tanaman sawi anorganik terlihat ada beberapa perbedaan dari jumlah daun dan berat tanaman.

Pada tabel 1 terlihat bahwa rata-rata tekanan oksigen yang dihasilkan pada tanaman organik yaitu $0,123 \mathrm{hPa} / \mathrm{s}$ sedangkan rata-rata tekanan oksigen yang dihasilkan pada tanaman anorganik yaitu $0.028 \mathrm{hPa} / \mathrm{s}$. Dari data ini terlihat bahwa tekanan oksigen tanaman sawi hijau organik lebih besar dibandingkan dengan tanaman sawi hijau anorganik. Semakin besar tekanan oksigen yang yang dihasilkan oleh suatu tanaman maka semakin cepat pula proses fotosintesisnya berlangsung. Sebaliknya, jika semakin rendah tekanan oksigen yang dihasilkan maka kecepatan fotosintesisnya semakin lambat sehingga peningkatan tekanan oksigen ini sangat mempengaruhi kecepatan fotosintesis. Hal ini didasarkan oleh reaksi yang terjadi pada reaksi terang yaitu:

Sinar matahari $+\mathrm{ADP}+\mathrm{Pi}+\mathrm{NADP}^{+}+2 \mathrm{H}_{2} \mathrm{O}$

$\rightarrow \mathrm{ATP}+\mathrm{NADPH}+3 \mathrm{H}^{+}+\mathrm{O}_{2}$

Berdasarkan reaksi ini dapat dilihat bahwa pada reaksi terang tanaman menghasilkan oksigen, sehingga besar tekanan oksigen ini dapat dijadikan parameter untuk mengukur kecepatan fotosintesis suatu tanaman.

Dari data tabel 1, rata-rata tekanan oksigen tanaman organik pada reaksi gelap yaitu $-0.104 \mathrm{hPa} / \mathrm{s}$ sedangkan pada tanaman anorganik $-0.037 \mathrm{hPa} / \mathrm{s}$. Penurunan tekanan oksigen pada reaksi gelap ini menunjukkan bahwa baik pada tanaman sawi hijau organik maupun tanaman sawi hijau anorganik samasama tidak menghasilkan oksigen melainkan menggunakan energi yang dihasilkan pada reaksi terangnya. Semakin besar angka penurunan tekanan oksigennya maka semakin cepat tanaman tersebut memasuki fase reaksi gelap. Hal ini didasarkan oleh reaksi yang terjadi pada reaksi gelap dimana senyawa kimia berenergi tinggi $\left(\mathrm{NADPH}_{2}\right.$ dan ATP) yang dihasilkan pada reaksi terang digunakan untuk reaksi reduksi $\mathrm{CO}_{2}$ menjadi Amilum dengan bantuan enzim Rubisco sebagai penambat $\mathrm{CO}_{2}$. Reaksi sederhana yang terjadi yaitu sebagai berikut:

\section{$\mathrm{CO}_{2}+\mathrm{RuBP} \longrightarrow$ Amilum}

Fiksasi $\mathrm{CO}_{2}$ merupakan reaksi gelap yang distimulasi oleh pencahayaan kloroplas. Fiksasi $\mathrm{CO}_{2}$ melewati proses karboksilasi, reduksi, dan regenerasi. Karboksilasi melibatkan penambahan $\mathrm{CO}_{2}$ dan $\mathrm{H}_{2} \mathrm{O}$ ke RuBP membentuk dua molekul 3fosfogliserat(3-PGA). Kemudian pada fase reduksi, gugus karboksil dalam 3-PGA direduksi menjadi 1 gugus aldehida dalam 3fosforgliseradehida (3-Pgaldehida). Reduksi ini tidak terjadi secara langsung, tapi gugus karboksil dari 3-PGA pertama-tama diubah menjadi ester jenis anhidrida asam pada asam 1,3-bifosfogliserat (1,3-bisPGA) dengan penambahan gugus fosfat terakhir dari ATP. ATP ini timbul dari fotofosforilasi dan ADP yang dilepas ketika 1,3-bisPGA terbentuk, yang diubah kembali dengan cepat menjadi ATP oleh reaksi fotofosforilasi tambahan. Bahan pereduksi yang sebenarnya adalah NADPH, yang menyumbang 2 elektron. Secara bersamaan, Pi dilepas dan digunakan kembali untuk mengubah ADP menjadi ATP. Pada fase regenerasi, yang diregenerasi adalah RuBP yang diperlukan untuk bereaksi dengan $\mathrm{CO}_{2}$ tambahan yang berdifusi secara konstan ke dalam dan melalui stomata. Pada akhir reaksi Calvin, ATP ketiga yang diperlukan bagi tiap molekul $\mathrm{CO}_{2}$ yang ditambat, digunakan untuk mengubah ribulosa-5-fosfat menjadi RuBP, kemudian daur dimulai lagi. Tiga putaran daur akan menambatkan 3 molekul $\mathrm{CO}_{2}$ dan produk akhirnya adalah 1,3Pgaldehida. Sebagian digunakan kloroplas untuk membentuk pati, sebagian lainnya 
dibawa keluar. Sistem ini membuat jumlah total fosfat menjadi konstan di kloroplas, tetapi menyebabkan munculnya triosafosfat di sitosol. Triosa fosfat digunakan sitosol untuk membentuk sukrosa (Anonim, 2010).

Kecepatan fotosintesis tanaman pada penelitian ini dapat dipengaruhi oleh beberapa hal. Pemberian pupuk yang berbeda pada kedua tanaman ini sangat menentukan tersedianya unsur-unsur hara yang cukup di dalam tanah yang dibutuhkan tanaman untuk dapat melakukan proses fotosintesis. Menurut Arnon dan Stout ada tiga kriteria yang harus dipenuhi sehingga suatu unsur dapat disebut sebagai unsur esensial:

a. Unsur tersebut diperlukan untuk menyelesaikan satu siklus hidup tanaman secara normal.

b. Unsur tersebut memegang peran yang penting dalam proses biokimia tertentu dalam tubuh tanaman dan peranannya tidak dapat digantikan atau disubtitusi secara keseluruhan oleh unsur lain.

c. Peranan dari unsur tersebut dalam proses biokimia tanaman adalah secara langsung dan bukan secara tidak langsung.

Penggunaan pupuk organik pada tanaman memiliki lebih banyak keuntungan dibandingkan dengan menggunakan pupuk anorganik. Salah satunya yaitu pada kandungan unsur hara yang ada pada pupuk organik. Pada pupuk organik unsur hara yang terkandung yaitu Karbon (C), Nitrogen (N), Fosfor (P) dan Kalium (K) serta beberapa unsur hara mikro seperti Magnesium $(\mathrm{Mg})$ dan Kalsium (Ca). Tanaman memerlukan unsur hara yang cukup dalam melakukan berbagai proses metabolisme salah satunya yaitu proses fotosintesis. Penggunaan pupuk organik dapat membantu dalam penyediaan unsur $\mathrm{P}$ dalam tanah yang sangat dibutuhkan dalam proses fotosintesis.

Karbon $(\mathrm{C})$, Oksigen $\left(\mathrm{O}_{2}\right)$ dan Hidrogen (H) merupakan bahan baku dalam pembentukan jaringan tubuh tanaman, berada dalam bentuk $\mathrm{H}_{2} \mathrm{O}$ (air), $\mathrm{H}_{2} \mathrm{CO}_{3}$ (asam karbonat) dan $\mathrm{CO}_{2}$ (gas karbondioksida). Karbon adalah unsur penting sebagai pembangun bahan organik, karena sebagian besar bahan kering tanaman terdiri dari bahan organik. Unsur Karbon (C), ini diserap tanaman dalam bentuk gas $\mathrm{CO}_{2}$ yang selanjutnya digunakan dalam proses yang sangat penting yaitu fotosintesis:

$$
\mathrm{CO}_{2}+\mathrm{H}_{2} \mathrm{O} \longrightarrow \mathrm{C}_{6} \mathrm{H}_{12} \mathrm{O}_{6}
$$

Tanpa gas $\mathrm{CO}_{2}$ proses tersebut akan terhambat sehingga pertumbuhan dan produksi tanaman pun akan terhambat. Sama halnya dengan karbon, ternyata Hidrogen $(\mathrm{H})$ merupakan elemen pokok pembangunan bahan organik dan unsur $\mathrm{H}$ ini diserap oleh tanaman dalam bentuk $\mathrm{H}_{2} \mathrm{O}$. Esensi unsur ini bagi tanaman adalah pada proses fotosintesis $\left(\mathrm{CO}_{2}+\mathrm{H}_{2} \mathrm{O}\right.$ $\mathrm{C}_{6} \mathrm{H}_{12} \mathrm{O}_{6}$ ) di sini jelas terlihat bahwa, unsur $\mathrm{H}$ sama pentingnya dengan unsur.

Pada penelitian ini (gambar 1 dan 2), terlihat perbedaan pada rata-rata peningkatan tekanan oksigen pada reaksi terang dimana pada tanaman organik pada detik pertama hanya $8,70 \mathrm{hPa} / \mathrm{s}$ dan berakhir pada detik ke 60 dengan angka 15,63 hPa/s (Lihat hal.69), sedangkan pada tanaman anorganik $0,97 \mathrm{hPa} / \mathrm{s}$ hingga pada detik ke 60 hanya mencapai angka $2,60 \mathrm{hPa} / \mathrm{s}$. Pada reaksi gelap juga kedua tanaman mengalami perbedaan pada tingkat penurunan tekanan oksigen \nya. Pada tanaman sawi organik mengalami penurunan dari 10,30 $\mathrm{hPa} / \mathrm{s}$ pada detik pertama hingga $4,70 \mathrm{hPa} / \mathrm{s}$ pada detik ke 60 (Lihat hal.73), sedangkan pada tanaman sawi anorganik mengalami penurunan dari $4,47 \mathrm{hPa} / \mathrm{s}$ pada detik pertama hingga $2,27 \mathrm{hPa} / \mathrm{s}$ pada detik ke 60 . Dari data tersebut terlihat selisih antara kedua tanaman tersebut sangat jauh berbeda. Perbedaan ini terjadi karena pada pemberian pupuk pada kedua tanaman yang dilakukan sebanyak dua kali selama 6 minggu, pada tanaman sawi yang diberi pupuk anorganik ternyata tidak dapat memenuhi unsur hara yang diperlukan oleh tanaman sehingga pada saat dilakukan pengukuran tekanan oksigen yang dihasilkan tanaman sawi anorganik ini dalam proses fotosintesis juga sangat rendah. Sebaliknya pada tanaman sawi hijau organik, tekanan oksigen yang dihasilkan lebih besar karena penyediaan unsur hara pada tanaman saat dilakukan pengukuran tekanan oksigen masih mencukupi. 
Beberapa hasil penelitian yang lain menunjukkan bahwa bahan organik dapat meningkatkan ketersediaan Kalium dan Posfor dalam tanah lebih lama dibandingkan dengan bahan anorganik. Untuk melakukan proses fotosintesis, tanaman melakukan penyerapan unsur hara dari tanah secara berkala sesuai dengan kebutuhannya. Penggunaan pupuk organik ini dapat membantu tanaman dalam penyerapan unsur hara karena pupuk organik tidak mudah larut dalam air tanah sehingga ketersediaan unsur hara pada tanaman tidak cepat habis. Pupuk organik yang berbentuk koloidal dalam tanah dan bermuatan negatif juga mudah dikoagulasikan oleh kation dan partikel tanah sehingga berbentuk granular. Oleh karena itu pupuk organik juga dapat memperbaiki struktur, tekstur dan kelembutan tanah.

Pada pupuk anorganik, hampir memiliki kandungan unsur hara yang sama dengan pupuk organik. Namun pupuk anorganik memiliki unsur kimia yang besar akibat penambahan beberapa zat kimia untuk memenuhi ketersediaan unsur haranya sehingga penggunaan pupuk ini memiiliki resiko yang lebih tinggi yang dapat berdampak bagi tanaman. Resiko lain dari penggunaan pupuk anorganik ini yaitu penyediaan nutrisi dan unsur hara tanaman didalam tanah lebih cepat habis sehingga mengharuskan dilakukan pemupukan secara bertahap untuk tetap memenuhi kebutuhan unsur hara tanaman dalam melakukan proses fotosintesis. Salah satu resiko lain dari penggunaan pupuk anorganik ini yaitu bahwa dari waktu ke waktu, penggunaan pupuk anorganik secara berangsur-angsur dapat mengubah keseimbangan gizi tanah (Kartasapoetra dan Sutedjo, 2000).

Berdasarkan sifat pupuk anorganik dan sifat hara dalam tanah, pupuk $\mathrm{N}$ dan $\mathrm{K}$ diberikan setelah tanaman dapat menyerap unsur hara dalam tanah. Pemupukan pertama diberikan pada tanaman berumur 7-10 hari $(<$ 14 hari). Pupuk N dan $\mathrm{K}$ diberikan lebih dari satu kali, pada tanah berpasir diberikan $>2$ kali (Kasno 2009).

Ketersediaan unsur hara oleh penggunaan pupuk organik dan anorganik ini juga mempengaruhi pada pertumbuhan tanaman. Hal ini dapat dilihat dari data pertumbuhan yang ditunjukkan pada hasil pengamatan selama 6 minggu yaitu rata-rata jumlah daun pada tanaman organik memiliki 7 helai daun sedangkan pada tanaman anorganik rata-rata 6 helai daun. Pada warna daun tidak begitu tampak perbedaan hanya pada beberapa batang tanaman ada yang daunnya cepat menguning hal ini dikarenakan asupan nutrisi dan hara yang diperoleh tidak tersebar secara merata ke suluruh bagian tumbuhan. Pada saat dilakukan penimbangan untuk mengetahui berat tanaman sebelum dilakukan penelitian juga memiliki perbedaan. Rata-rata berat tanaman organik adalah 4,109 gr sedangkan berat rata-rata tanaman anorganik 3,706 gr.

Pertumbuhan ini merupakan proses pertambahan substansi biomassa atau materi biologi yang dihasilkan dari proses-proses biosintesis di dalam sel yang bersifat endergonik dan bersifat irreversible. Gejala pertumbuhan dapat tampak melalui pertambahan berat, volum atau tinggi tanaman. Untuk pertumbuhannya, tumbuhan membutuhkan bermacam-macam hara, baik hara makro seperti $\mathrm{C}, \mathrm{H}, \mathrm{O}, \mathrm{N}, \mathrm{S}, \mathrm{P}, \mathrm{Ca}$ dan $\mathrm{Mg}$, maupun hara mikro seperti $\mathrm{Mn}, \mathrm{Cu}, \mathrm{Mo}$, $\mathrm{Zn}$, dan Fe. Bahan organik, pupuk kandang atau organik merupakan bagian penting dalam sistem tanah.

\section{KESIMPULAN}

1. Hasil penelitian ini menunjukkan rata-rata peningkatan tekanan oksigen tanaman sawi yang diberi pupuk organik pada reaksi terang sebesar $0.123 \mathrm{hPa} / \mathrm{s}$ sedangkan pada tanaman sawi yang diberi pupuk anorganik sebesar $0.028 \mathrm{hPa} / \mathrm{s}$. Dari data ini terlihat bahwa tekanan oksigen tanaman organik lebih besar dibandingkan dengan tanaman anorganik sehingga kecepatan fotosintesis tanaman sawi hijau yang diberi pupuk organik lebih cepat dibandingkan tanaman sawi hijau yang diberi pupuk anorganik.

2. Pada reaksi gelap rata-rata tekanan oksigen tanaman organik mengalami penurunan menjadi $-0.104 \mathrm{hPa} / \mathrm{s}$ sedangkan pada tanaman anorganik $-0.037 \mathrm{hPa} / \mathrm{s}$. Dari data diatas terlihat bahwa angka penurunan 
tekanan oksigen pada tanaman sawi hijau yang diberi pupuk organik lebih besar dibandingakan tanaman sawi hijau yang diberi pupuk anorganik dimana semakin besar angka penurunan tekanan oksigennya maka semakin cepat tanaman tersebut memasuki fase reaksi gelap.

Adapun saran yang bisa diberikan setelah melakukan penelitian ini agar para penelitian selanjutnya memperhatikan waktu pemberian pupuk yang harus dilakukan secara rutin terutama pada penggunaan pupuk anorganik. Saran lain yang dapat diberikan adalah selama waktu tumbuh tetap memperhatikan pertumbuhan dan perkembangan yang ditunjukkan oleh tanaman.

\section{DAFTAR PUSTAKA}

Bassham JA. 1965. Photosynthesis: The Path of Carbon. Plant Biochemistry. $2^{\text {nd }}$ ed. New York: Academic Press. pp 875-902.

Foyer CH. 1989. Photosynthesis. New York: Chapman and Hall.
Kartasapoetra AG dan Sutedjo. 2000. Pupuk dan Cara Pemupukannya. Jakarta: Rieneka cipta.

Kasno A. 2013. Pupuk Anorganik dan Pengelolaannya. Balai Pelatihan Tanah. http://balittanah.litbang.deptan.go.id. Diakses 1 April 2013.

Raven, Peter H, Ray FE, Susan EE. 2005. Biology of Plants 7th Edition. New York: W.H. Freeman and Company Publishers.

Syarief F. 2003. Respon PenggunaanPupuk Organik dan Anorganik terhadap Efesiensi Radiasi Surya pada Tanaman Padi. Bogor: Jurusan Geofisika dan Meteorologi FMIPA Institut Teknologi Bandung.

Taiz L and Zeiger E. 2002. Plant Physiology Third Edition. Sunderland: Sinauer Associates.

Utami, SN dan Handayani S. 2003. Sifat Kimia Entisol pada Sistem Pertanian Organik. Yogyakarta: Jurusan Ilmu Tanah Fakultas Pertanian Universitas Gadjah Mada. 